\title{
Quality status of drinking water sources in Gombe Metropolis of Nigeria
}

\author{
S. S. Hati ${ }^{1}$, G. A. Dimari ${ }^{2}$ and N. Ngueadoum ${ }^{3}$ \\ ${ }^{1}$ Department of Chemistry, IBB University, Lapai - Nigeria \\ ${ }^{2}$ Department of Chemistry, University of Maiduguri, Maiduguri - Nigeria \\ ${ }^{3}$ Department of Chemistry, Gombe State University, Gombe - Nigeria
}

\begin{abstract}
Quality status of sources of drinking water supply in Gombe metropolis was investigated and was found to have generally improved significantly within the last decade as a result of intervention of the State, Federal Government of Nigeria and international agencies such as the UNICEF/DFID. The study revealed that groundwater (borehole, hand pump well) is the largest source of drinking water in Gombe metropolis and only about $36 \%$ of the metropolis has direct access to treated drinking water. The quality status of the drinking water sources analysed revealed that in comparison with the USEPA reference standard, drinking water in Gombe metropolis is generally within acceptable limits. Sustainability and management of drinking water sources in the metropolis would depend on the improvement of sanitation status around public water supply, regular monitoring by responsible authorities to ensure safety of drinking water supply in Gombe Metropolis.
\end{abstract}

Keywords: Gombe; drinking water; potability; accessibility; sustainability

\section{INTRODUCTION}

Gombe is the metropolitan area of Gombe State, "Jewel in the savannah", Nigeria. The state was created on $1^{\text {st }}$ October, 1996 and comprises of eleven local government areas. Since its creation, the state was beset with inadequate public water supply especially within the metropolis, until 2006 when the water treatment plant was commissioned. The Dadinkowa dam is the primary source of water for the treatment plant, completed in 1984 and dams portions of River Gongola. The water treatment plant, completed in 2006 , is about $3 \mathrm{~km}$ from the dam, and is designed to discharge about $2000 \mathrm{~m}^{3} / \mathrm{h}$ capacity of clean treated water, but only about $50 \%$ of this is met (Ejiogu 2010).

Previously, drinking water sources in Gombe metropolis are mainly private owned boreholes and wells. Thus the larger populace purchase drinking water in the form of sachet water bags or water tanker supply. However, with the intervention of the State, Federal Government of Nigeria and international agencies such as United Nations Children Fund / Department for International Development (UNICEF/DFID) many boreholes have been dug in Gombe (DFID 2009) and public water supply improved. According to Limlim (2008) access to clean water and sanitation is generally improving, but at a slow pace. Available statistics indicate that access to basic sanitation and water supply in the country is still less than 50 percent. In view of the fact that adequate water supply is strongly linked to sanitation (Daley et al. 2004), the global call for adequate access to water and sanitation is of crucial concern as more than 1.2 billion people in the world lack access to safe drinking water and 2.6 billion lack access to even basic sanitation (WHO/UNICEF 2000; Fragio 2005).

Lack of access to safe drinking water and adequate sanitation has been noted to be one of the world's greatest humanitarian, social and developmental challenges, capable of hampering global poverty alleviation and sustainable development (Daley et al. 2004). Inadequate drinking water supply in Nigeria have been well documented (Fragio 2005; Jimoh and Wojuola 2009; Dada 2009). Available water sources are becoming depleted, aggravated by increased population growth, urbanization, climate change and existing un-sustainability factors and risks inherent to conventional urban water management, especially in developing countries (Khatri and Vairavamoorthy 2007).

Again, there is the issue of waterborne or waterrelated diseases (including diarrhea, cholera, typhoid, malaria, hepatitis and more), which are linked to an estimated $80 \%$ of illnesses in developing countries (WHO/UNICEF 2000). 
Therefore the main objective of this paper is to examine the quality status of drinking water sources in Gombe metropolis. It also attempts to support the nation-wide survey exercise which brought into focus a number of hindrances to proper management of water supply quality in Nigeria. These hindrances include lack of quality control and assurance, inadequate funding, poorly equipped or not functional laboratories, little or no attention placed on capacity building, lack of provision for compliance monitoring of recommended standards, poor state of record keeping and a total absence of a water quality data bank (Habila and Kehinde, 2003).

\section{MATERIALS AND METHODS}

Study area: Gombe metropolis is located between latitude 10'34 and 18'19N. It lies within the northeast region of Nigeria and occupies a total land area of about 20, $265 \mathrm{~km}^{2}$. The metropolis has an estimated population of 42 , 6053 (FRN 2007). The major climatic seasons are rainy or wet season (March or April to October) and the dry season (November to March or April). Annual rainfall ranges between 560 and $740 \mathrm{~mm}$ (July - October). The study area harbors the second largest dam in Nigeria and promotes sustainable agricultural activities such as the dry season farming through the irrigation system.

\section{Drinking water samples:}

For this work drinking water samples refer to water intended primarily for human consumption but which has other domestic and industrial uses. Sampling was conducted on three major sources of drinking water. These include tap water (municipal water supply), ground water (hand pumps/boreholes; well) and sachet (packaged water) samples. Thirty sampling locations from six different clusters and four prominent sachet water producers were maintained for this work. All samples were collected in sterile plastic bottles according to standard methods (Radojevic and Bashkin 2006). Sampling was carried out in JulyAugust 2008 and March-April 2009.

Experimental methods: Drinking water samples were prepared for physicochemical determinations according to standard procedures described by Ademoroti (1996) and Radojevic and Bashkin (2006).

Temperature and $\mathrm{pH}$ measurements were conducted on-site with portable meters at approximately $25^{\circ} \mathrm{C}$ using model $3310 \mathrm{pH}$ meter (Jenway Ltd, Dunmow, UK). The $\mathrm{pH}$ meter and electrode was calibrated with buffer solutions of $\mathrm{pH} 7$ and 4 for $\mathrm{pH}$ determinations. Conductivity measurements were carried out using model 4150 conductivity meter (Jenway Ltd, Dunmow, UK). This was calibrated with standard potassium chloride solution and results presented in $\mu \mathrm{S} \mathrm{cm}^{-1}$. Hardness of drinking water samples were determined using direct complaxation titration with ethylene-diammine-tetra-acetic acid, EDTA $(0.01 \mathrm{M})$. This was standardized against standard calcium solution. $100 \mathrm{ml}$ of water sample was measured, $1 \mathrm{ml}$ of buffer was added proportionally with Eriochrom Black-T indicator and then titrated with the EDTA solution slowly from a micro burette. The change from red colour to blue coloured showed the end point.

Chloride ions were determined using titrimetric method. Drinking water samples, $50 \mathrm{ml}$ each, was placed in a $100 \mathrm{ml}$ conical flask and made up to the mark with distilled water, $0.1 \mathrm{ml}$ of $\mathrm{K}_{2} \mathrm{CrO}_{4}$ was added and titrated against $0.0282 \mathrm{M} \mathrm{AgNO}_{3}$.

The standard calibration method of Flame atomic absorption spectrometry (FAAS) was used to determine $\mathrm{Fe}, \mathrm{Mg}, \mathrm{Zn}, \mathrm{Cd}, \mathrm{Pb}$ in the water samples, using AA-6800 (Shimadzu, Japan) equipped with ASC-6100 auto sampler and airacetylene atomization gas mixture.

Total coliform bacteria were determined in the drinking water samples using the multiple tube fermentation tests and the calculated coliform density computed by the Most Probable Number (MPN) procedures (APHA, 1998). All measurements of parameters at each sampling stations were made in triplicates.

Results obtained were statistically analyzed using Analyse-it $\circledast$ v.2.20, statistical software for Microsoft Excel. Variations were considered significant at $p<0.05$.

\section{RESULTS AND DISCUSSION}

Assessment result of drinking water sources revealed that Gombe metropolis depends on ground water (hand pump well; boreholes), tap water (municipal water supply) and sachet water (packaged water). The result (Table 1) shows that about $64 \%$ of the total samples analysed in this work are ground water. Based on the sampling clusters used, this indicates the approximate percentage of dependence of the populace on the various sources of drinking water in the metropolis. Therefore, it also shows that since the completion of the municipal water supply system in 2006 , about $36 \%$ of the metropolis now has direct access to treated drinking water. This level 
and rate of improvement is significantly positive in relation to the number of interventions over the years (DFID 2009).

Table 1 Percent level of drinking water source analysed

\begin{tabular}{|l|r|}
\hline Sources & \% Sample \\
\hline Ground water & 64 \\
\hline Tap water & 23 \\
\hline Sachet water & 13 \\
\hline
\end{tabular}

Table 2 shows summary result of quality status of drinking water samples analysed. Values of quality assessment parameters obtained were compared with the maximum contamination levels (MCL) of the United State Environmental Protection Agency (USEPA) standards for drinking water (Gray 2008), which covers secondary standards and public health goal. The result revealed that water samples analysed were all within ambient limits, with average temperature of $30^{\circ} \mathrm{C}$. This reflects the average ambient temperature of this region during the periods of assessment (Nduka and Orisakwe 2007).

The $\mathrm{pH}$ values of water samples analysed indicated that only about $7 \%$ of sampling locations

Table 2 Summary result of quality status of drinking water

\begin{tabular}{|c|c|c|c|c|c|c|}
\hline Parameter & Min & Max & Mean & SD & $\begin{array}{l}\text { USEPA } \\
(2006) \\
\text { MCL }^{a}\end{array}$ & $\begin{array}{l}\% \text { Sample } \\
\text { Location } \\
\text { within MCL }\end{array}$ \\
\hline Temperature $\left({ }^{\circ} \mathrm{C}\right)$ & 28.00 & 33.40 & 30.00 & 1.39 & Ambient & 100 \\
\hline $\mathrm{pH}$ & 5.79 & 8.85 & 6.77 & 0.80 & $6.5-8.5$ & 93 \\
\hline Hardness & 54.80 & 276.30 & 163.41 & 61.32 & $<100^{b}$ & 17 \\
\hline Conductivity $\mu \mathrm{S} \mathrm{cm}^{-1}$ & 104.00 & 1231.00 & 524.67 & 267.77 & 180 & 7 \\
\hline $\mathrm{Cl}$ & 47.69 & 276.96 & 137.20 & 67.82 & 250 & 90 \\
\hline $\mathrm{Cd}$ & \multicolumn{4}{|l|}{ ND } & 0.005 & - \\
\hline $\mathrm{Fe}$ & 0.01 & 0.18 & 0.10 & 0.05 & 0.3 & 100 \\
\hline $\mathrm{Mg}$ & 1.92 & 4.35 & 3.41 & 0.85 & - & - \\
\hline $\mathrm{Pb}$ & 0.13 & 1.16 & \multicolumn{2}{|l|}{$\mathrm{C}^{\mathrm{C}}$} & 0.0 & 93 \\
\hline $\mathrm{Zn}$ & 0.02 & 0.22 & 0.09 & 0.06 & 5.0 & 100 \\
\hline Coliform (MPN/100ml) & 0.0 & 167.00 & 113.12 & 40.27 & 0.0 & 13 \\
\hline
\end{tabular}

were above the MCL and are not statistically significant in terms of number of locations and variations between standard and values obtained from analysed samples. The $\mathrm{pH}$ values obtained in this work correspond to the values reported by other researchers (Dada 2009; Ndukwe and Orisakwe 2007). The concerns for drinking water $\mathrm{pH}$ are mainly the corrosion of distribution system which may eventually poses health hazards.

Sources of drinking water in this region are generally known to be hard due to scaling observed in pipes, household wares and difficulties associated with leather formation during washing. This is however, confirmed by the result of this work which shows that only $17 \%$ of the total samples analysed were within the standard limits. Water hardness is usually caused by divalent cations such as $\mathrm{Ca}^{2+}$ and $\mathrm{Mg}^{2+}$ (Gray 2008) and is associated with limestone catchment areas. Gombe metropolis and environs is known for several mineral deposits including limestone within the Northeastern region of Nigeria. This perhaps accounts for the high values of water hardness recorded in this work. However, the correlation plot (Fig. 1) shows that $\mathrm{Mg}$ is not strongly associated with the general hardness of water observed. 
Conductivity values of potable water usually express the measure of concentration of ionized substances (minerals) in water. Highly mineralized water register conductance value above $500 \mu \mathrm{S} \mathrm{cm} \mathrm{cm}^{-1}$, however in this work the MCL value of $180 \mu \mathrm{S} \mathrm{cm}^{-1}$ is related to natural spring water. The results of this work revealed that only $7 \%$ of total sample analysed were within the MCL. Though a maximum conductance value of $1231.1 \mu \mathrm{S} \mathrm{m}^{-1}$ was recorded in this work, but an overall $53 \%$ of total sample were above $500 \mu \mathrm{S} \mathrm{cm}^{-1}$. This shows that a greater percentage of drinking water in Gombe metropolis is highly mineralized. Conductivity is closely related to salinity and ions that have a major influence on the conductance value of drinking water are $\mathrm{H}^{+}, \mathrm{Na}^{+}, \mathrm{K}^{+}, \mathrm{Ca}^{2+}, \mathrm{Mg}^{2+}, \mathrm{Cl}^{-}, \mathrm{SO}_{4}{ }^{2-}$, and $\mathrm{HCO}_{3}{ }^{-}$((Manahan 2005; Radojevic and Bashkin 2006).

The result of chloride concentration in drinking water sample analysed show that up to $90 \%$ of total sample were within the MCL, the remain $10 \%$ were actually recorded from treated water samples. The maximum chloride value recorded was about $277 \mathrm{mg} / \mathrm{L}$ which is not significantly higher than the MCL. Chloride in drinking water also has significance from public health perspective as it is applied in disinfection of public water supply. The result also indicates an appreciably good treatment practice at the treatment plant.

Results of elemental content of drinking water samples analysed in this work show that $\mathrm{Cd}$ was not detected in water because it is rarely found in water (Mohan et al 1996), while the other elements were within the MCL. Generally the concentration range of the elements was not uniformly distributed.

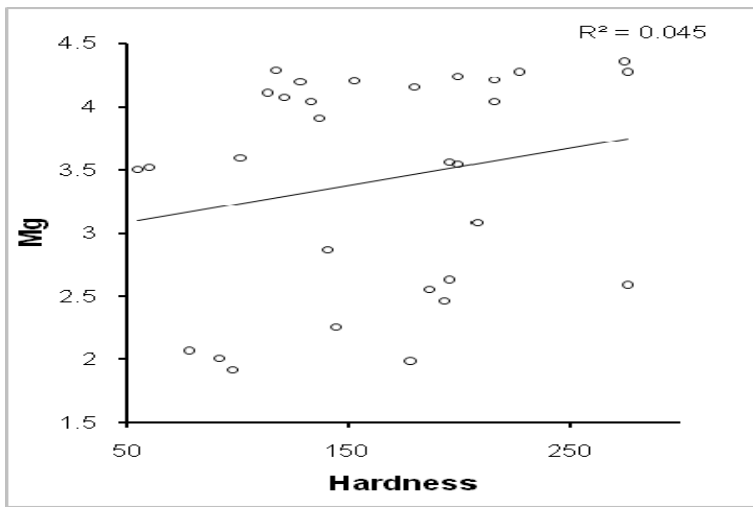

Fig. 1. Correlation plot of Hardness and Mg content
However, $\mathrm{Pb}$ was detected at concentrations beyond the $\mathrm{MCL}$ at two different locations. Usually $\mathrm{Pb}$ pollution results from automobile emission, industrial effects, others agricultural activities which is toxic and can cause brain damages, and also destroy the kidney (Zaslow and Herman 1996; Parks and Edwards 2002). The River Gongola, which is another source of drinking water that runs across this area has been analysed and recommended not safe for consumption due to heavy metal and microbial contamination (Sabo et al. 2008). It was however observed that some of the drinking water sources in the metropolis where metal storage facilities were the sources of $\mathrm{Pb}$ pollutants detected in the water samples.

Microbial assessment of drinking water is a good indicator of potential waterborne diseases (Plummer and Long 2007). In this work, over $80 \%$ of total samples analysed were above the MCL for microbial content. The public health goal for this is zero. Though most packaged water apparently was of good quality, but some are contaminated. Therefore packaged water in sachets is not to be automatically assumed safe; they are likely to be compromised significantly on transit from manufacturer to the consumer (Dada 2009). Open waste sites, poor sanitation and landfill leachates around drinking water sources due to human habitation.

Results of drinking water quality status reported in this work generally correspond with values reported in other parts of Nigeria (Adekunle et al. 2007; Dada 2009). It was also observed that some of the likely sources of contaminants in drinking water sources in Gombe metropolis include metal storage facility, sanitation conditions of Private Dam of water seller, public hand pump borehole and public municipal water supply as shown in Fig. 3.

As population growth and urbanization continues to affect drinking water sustainability and management (Zekster and Aswathanarayana 1998; Herbst 2008), in Gombe metropolis, however, the improvement of drinking water quality and supply is necessary and would entail piped supply into dwelling or plot and improved sanitation status of surroundings as well. This would considerably improve on the quality drinking water as against unprotected source of drinking water supply system which poses health hazard. 

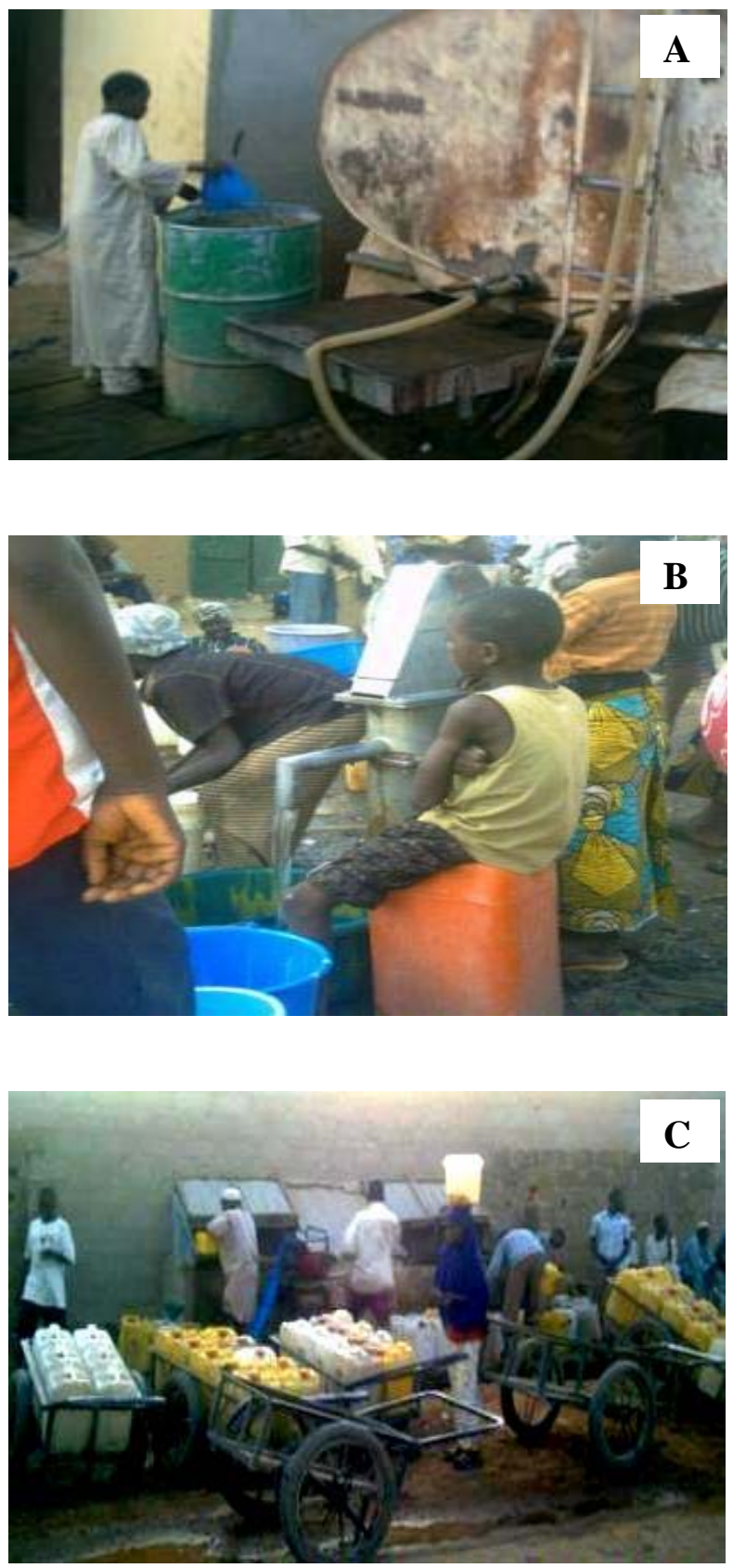

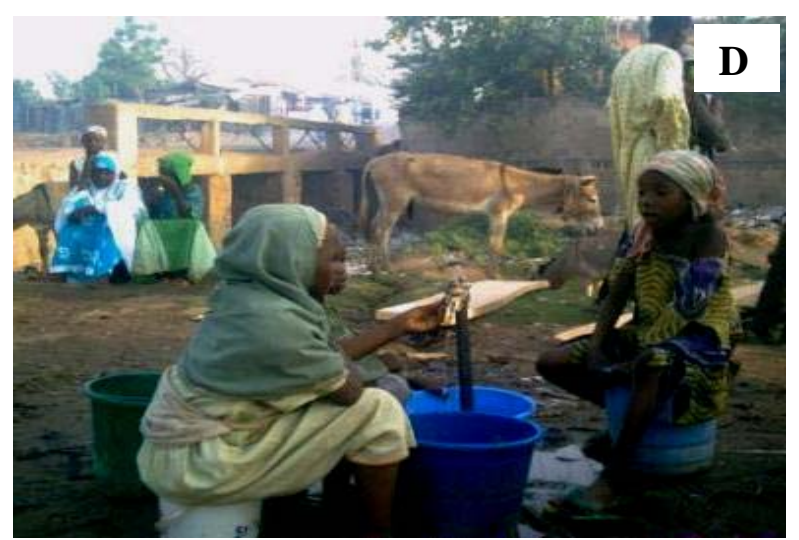

Fig. 2. Sources of contaminants in drinking water sources of Gombe metropolis. (A: Metal storage facility; B: Public hand pump borehole; C: Private Dam of water seller; D: Public Municipal water supply)

\section{CONCLUSION}

(1) The study indicated that groundwater (borehole, hand pump well) is the largest source of drinking water in Gombe metropolis and only about $36 \%$ of the metropolis has direct access to treated drinking water. Drinking water supply has generally improved significantly within the last decade as a result of intervention of the State, Federal Government of Nigeria and international agencies such as the UNICEF/DFID.

(2) Quality status of the drinking water sources analysed revealed that in comparison with the USEPA reference standard, drinking water in Gombe metropolis is generally within acceptable limits.

(3) Sustainability and management of drinking water sources in the metropolis would depend on the improvement of sanitation status around public water supply, regular monitoring by responsible authorities to ensure safety of drinking water supply in Gombe Metropolis. 


\section{REFERENCES}

Adekunle1, I.M., Adetunji, M.T., Gbadebo, A.M. and Banjoko, O.B. (2007) Assessment of Groundwater Quality in a Typical Rural Settlement in Southwest Nigeria, Int. J. Environ. Res. Pub. Health, 4, 307-318

Ademoroti, C.M.A. (1996) Standard Methods for Water and Effluents Analysis Physico-Chemical Examination, pp. 21-23. University of Benin Press, Nigeria.

APHA: American Public Health Association (1998) Standard Methods for the Examination of Water and Wastewater (20th edn. pp. 23-54). Washington DC, USA.

Basualto, S., Tapia, J., Cruces, F., Penacortes, F., Hauenstein, E., Bertran, C. and Schlatter, C. (2006) The Effect Of Physical and Chemical Parameters in Drinking Water: Physico-Chemical Test Determination, J. Chilean Chem. Soc. 51, 993-999.

Dada, A.C. (2009) Sachet Water Phenomenon in Nigeria: Assessment of the Potential Health Impacts, African $\mathrm{J}$. Microbiol. Res., 3, 15-21.

Daley, R.J., Adeel, Z., Mayfield, C.I., King, C. and Grover, V.I. (2004) Safe Drinking Water and Sanitation for All, a G20-Led Initiative, Background Discussion Paper for the G20 Water Policy Workshop. pp. 5, 23. Alexandria, Egypt.

DFID: Department for International Development (2009) Meeting Our Promises 2009. The Fifth Update on DFID's Work in Water and Sanitation Since the 2004 Water Action Plan, pp. 1-35. Crown London.

Ejiogu, E. (2010) Suddenly, Gombe gallops fast, The Sun News Online, Sunday March 21. http://www.sunnewsonline.com

Fragio, A.G. (2005) The European Response to the Challenges of Water and Sanitation in Developing Countries, Tribune 2, 86-89.

FRN: Federal Republic of Nigeria (2007) Official Gazette: Legal Notice on Publication of the 2006 Census Report, 4(94) B, pp. 185-186. Lagos, Nigeria.

Gray, N.F. (2008) Drinking Water Quality (2nd edn. pp. 77116), Cambridge University Press, UK

Habila, O.N. and Kehinde, M.O. (2003) Public Water Supply Quality Management in Nigeria 29th WEDC International Conference Abuja, Nigeria. WEDC, 111114.

Herbst, S. (2008) Sanitation and Groundwater Protection: A WHO Perspective, Institute for Hygiene \& Public Health, pp. 1-20. University of Bonn, Germany.
Jimoh, O.D. and Wojuola, O.A. (2009) Shallow Aquifer Resources in the Federal Capital Territory of Nigeria, Water and Environ. J. 23, 41-45

Khatri, K.B. and Vairavamoorthy, K. (2007) Challenges for Urban Water Supply and Sanitation in the Developing Countries, Discussion Draft Paper for the session on Urbanisation Delft, pp. 2-20. UNESCO-IHE, Netherlands.

Limlim, R. (2008) Increasing Access to Water, Sanitation and Hygiene, UNICEF Nigeria Newsletter 1, 1-12

Manahan, S. E. (2005) Environmental Chemistry (8th edn. pp. 169-180; 687), CRC Press LLC, USA.

Mohan, S.V., Nithila, P. and Redy, S. J. (1996) Estimation of Heavy Metals in Drinking Water and Development of Heavy Metals Pollution Index. J. Environ. Sci. Health, 31, 283-289.

Nduka, K.C. and Orisakwe, O.E. (2007) Some Physico Chemicals Parameters of Potable Water Supply in Warri, Niger Delta Area of Nigeria. Urban Water Journal, 5, 58-64

Parks, J. and Edwards, M. (2002) Lead Particles in Potable Water. J. Trop. Pediatrics 27, 46-51

Plummer, J.D. and Long, S.C. (2007) Monitoring Sources Water for Microbial Contamination: Evaluation of Water Quality Measures. Water Research, 41, 3716-3728.

Radojevic, M. and Bashkin, V.N. (2006) Practical Environmental Analysis (2nd edn. pp. 147-170). RSC Publishing, UK.

Sabo, A., Nayaya, A.J. and Galadima, A.I. (2008) Assessment of Some Heavy Metals in Water, Sediment and Freshwater Mudfish (Clarias gariepinus) from River Gongola in Yamaltu-Deba, Gombe, Nigeria. Int. J. Pure Appl.. Sci., 2, 6-12.

WHO/UNICEF (2000) Global Water Supply and Sanitation Assessment 2000 Report, WHO/UNICEF - Joint Monitoring Programme for Water Supply and Sanitation pp. 7-41. WHO, Switzerland

Zaslow, A. S. and Herman, G.M. (1996) Health effects of drinking water contaminants, Ox. J. Med., 19, 83-90.

Zekster, O and Aswathanarayana, J. (1998) Water Management and the Environment, pp. 418. Taylor and Francis, London. 